\title{
Have We Been Thinking Upside-Down? \\ The Contemporary Emergence of Pacific \\ Theoretical Thought
}

\section{Elise Huffer and Ropate Qalo}

\begin{abstract}
Pa acific thought is like a dormant volcano: as long as it does not erupt, no one notices it. When it does boil to the surface, it comes, to the many who would rather dismiss it, as an unpleasant reminder of its persistent existence. ${ }^{1}$ And when it settles again, it is easily forgotten. But we (whether researchers, educators, policymakers, donors, or others) ignore it at our peril.
\end{abstract}

Why should we be concerned about Pacific thought? Answers to this question are partially provided by the literature that has explored facets of national and local philosophies and epistemologies. Over the past thirtyfive years or so, Pacific theologians have examined how Samoan, Kiribati, Tuvaluan, Fijian, Tongan, Papua New Guinean, and other Pacific Islander fundamental concepts and philosophies are linked to the gospel and to Christianity in general in order to make the latter more relevant to their societies. ${ }^{2}$ They have mainly sought to show that, while Christianity cannot survive without integrating existing fundamental values of local societies (even though the Church has a checkered record on this issue), ${ }^{3}$ there are parallels and meeting points between the two systems of thought as well as areas where one may be enriched by the other.

Pacific educators at the University of the South Pacific (in particular, Konai Helu Thaman, Unaisi Nabobo, Teweiariki Teaero, and 'Ana Maui Taufe'ulungaki) have been conducting research on Pacific educational philosophies. ${ }^{4}$ Their concern has been to affirm the existence of particularly Pacific ways of learning and distinctive understandings of the nature of knowledge, wisdom, and intelligence-and to ensure that these become part of formal educational curricula in the region. Their work has focused

The Contemporary Pacific, Volume I6, Number I, Spring 2004, 87-II6

(C) 2004 by University of Hawai' $i$ Press 
on demonstrating that Tongan, Kiribati, Fijian, and other Pacific Islander values must be integrated in the schooling experience of students in the region, so that the experience is not only more relevant but also conducive to harmonious societies in the future. Similar work has been conducted at the National University of Sāmoa and at the University of Papua New Guinea. Beyond the walls of mainstream academic institutions, people like Motarilavoa Hilda Lini in Vanuatu and Ataria Waitea in Kiribati have been active in the development of community schools that, among other activities, teach indigenous philosophy.

In recent years indigenous and "Native Pacific Islander" scholars whose approaches defy narrow disciplinary constraints have begun to investigate Pacific epistemologies and ways of doing and being. ${ }^{5}$ Their work documents and interprets efforts by local communities they are associated with or part of, to validate and explore their own epistemologies and to renegotiate development on their own terms. This is particularly the case for David Welchman Gegeo (1998; and with Karen Watson-Gegeo [200I]); Manulani Aluli Meyer (200I); and Ropate Qalo, who has written a book about a family business run according to Fijian precepts of cooperation and a paper about the relationship between vakaviti (the Fijian way) and social capital (Qalo I997; I998). The concern of all these scholars is to affirm not only that indigenous epistemologies are alive and well, but also that they are relevant and useful to the societies and people to whom they belong and that they provide alternative ways of approaching economic and social development.

Other attempts at examining aspects of thought in various countries of the Pacific have come from philosophers such as Futa Helu in Tonga, Bernard Narokobi in Papua New Guinea, Jean-Marie Tjibaou in New Caledonia/Kanaky, Turo a Raapato in Tahiti, and John Patterson, author of a book on Māori values (I992).

In spite of the above literature, ignorance or dismissal of Pacific thought prevails in academia, which in turn has impacted on policymaking in Pacific countries. This situation is in part the result of disciplinary biases and omissions. ${ }^{6}$ While anthropologists have looked at many aspects of Pacific societies from a variety of perspectives, they have not sought to examine Pacific thought or systems of thought as a distinct or stand-alone category of study. ${ }^{7}$ In addition, as Gegeo and Watson-Gegeo stated, when "outside researchers, including anthropologists" have examined other cultures, they have done so from their own theoretical constructs, not from those of the societies they have observed (200I, 58). As for political sci- 
entists, they have largely focused on institutions, processes, and political forces and events, rather than on the political ideals and views of Pacific peoples and societies. Economists, for the most part, have been so busy promoting "development" and looking for ways to successfully integrate Pacific societies into the world of western economic rationalism that they have come to see Pacific attitudes as a constraint or barrier to their mission rather than as an area to be taken seriously.

While this brief discussion of available literature suggests that there is no constituted body of Pacific thought as such, it does confirm that areas of it have been explored from different perspectives. ${ }^{8}$ Those who have initiated this research recognize a need to give voice to ways of doing, thinking, and being that have been ignored or silenced. ${ }^{9}$ The voices are plural, reflecting the nature of the region. Concepts in one society do not always carry over into another; however, many similarities exist and may be drawn on in building a body of Pacific thought.

Constructing a body of thought, much like building a Samoan fale (house), has significance in itself, but it must first and foremost be of use to the community it is designed for. It must provide shelter from the outside elements and bring comfort to those inside. It must not shut out the world but be able to invite the world in, on its own terms. In short, a body of Pacific thought should contribute to the establishment or affirmation of a Pacific philosophy and ethic - a set of applicable concepts and values to guide interaction within countries, within the region, and with the rest of the world. The ethic must be acknowledged, understood, and respected by all who interact with Pacific Island communities. ${ }^{10}$

Many within and beyond the region may argue (and have argued) that Pacific values and ways of being and doing are obsolete; that they are not adapted to the demands of the contemporary world with its emphasis on the market economy and liberal democracy. ${ }^{11}$ The many failures of the market economy and liberal democracy within the region, however, constantly remind us of the importance of Pacific ways and values: one need only look at the coups in Fiji, the crisis in the Solomon Islands, and the corruption prevalent in most countries of the region (engaged in mainly by the elite, those most accustomed to western paradigms and methods). The incapacity within the region (and worldwide) to regulate distribution and ensure equity of wealth, and to provide basic health, education, employment, and sometimes even food security, raises some fundamental questions about value systems that we should begin to answer.

While this task appears daunting, we should remember that the condi- 
tion of "modernity" is an exception (albeit a very powerful one), not the norm worldwide (Aglietta et Orléan I998). Because much of thought production at the international level has digested and assimilated modernity, alternative thought systems have received relatively little attention (with some notable exceptions such as Edward Said and Frantz Fanon). ${ }^{12}$

This is particularly the case in the Pacific, a region very small in terms of population, or of political and economic power, but one of the most culturally diverse per capita in the world. It is also a region in which Christianity has had a very strong impact and where colonial and neocolonial powers have generally assumed that local communities would eventually assimilate the basic principles of the market economy and of liberal democracy, regardless of the destructuring impacts of these precepts.

There are different paths toward constructing Pacific thought. One is to encourage Pacific Islander students and researchers to conduct research in this area with their communities, and to convince donors and academic institutions to fund such research. Offering a course in Pacific thought to graduate students at the University of the South Pacific (an aim of the Institute of Pacific Studies) would promote this kind of research.

A second path is to support local communities that already engage in alternative economic development based on indigenous philosophies and an ethic of self-reliance. Another is for nongovernmental organizations and local leaders to work with communities to establish frameworks and positions based on their value systems, from which they can negotiate with regional, provincial, state, and international actors. All efforts that have already begun in this area should be strengthened.

A more modest path, which we begin to explore in this article, is to analyze some of the existing literature and work already being conducted by and within local communities along these lines, with a view to understanding why and how these efforts came about and where they can lead us.

\section{Pacific Values and Theology}

When first looking for written materials on which we could draw to develop a course on Pacific thought, we found that one of the most promising sources available was a body of theses written by theology students (and lecturers) associated mainly with the Pacific Theological College (PTC) in Suva, Fiji. This may seem ironic in light of the Church's role in undoing many cultural practices and proselytizing against so-called "primitive" beliefs, but it suggests that, in the long run, mainstream churches in 
the Pacific have to an extent been obliged to integrate (or at least to appear to integrate) cultural realities in order to be accepted. Selected theologians have been active in promoting the acknowledgement of Pacific values, and institutions such as Pacific Theological College and the Melanesian Institute for Pastoral and Socio-Economic Service in Goroka, Papua New Guinea (and certain principals and researchers within these institutions) have been at the forefront of research into the "contextualization," "indigenization," or even "inculturation" of theology. However, the push has not generally come from the national or local churches or in-country theological colleges: it has been much more of a top-down, academic initiative than a grassroots, practical one. Local churches and national theological colleges have, for the most part, been reluctant to rock the boat by stressing values they do not see as conforming to those of the gospel. The efforts of innovative theologians so far have generally had little impact either on the ground or in a wider "universal" or cross-cultural dialogue, ${ }^{13}$ but they have the merit of existing.

Thus, although Pacific theologians began grappling with the issue of contextualizing the Church some thirty-five years ago, it remains an ongoing project. The need to better integrate western theology and Pacific values has been proclaimed regularly, particularly at the regional level, ${ }^{14}$ but, in most cases, there has been little impact on how the gospel and theology are actually taught or brought to the people throughout the region. According to one PTC lecturer, this is due in part to the gap between the institutional level (such as that of PTC and other theological colleges in New Zealand, Australia, the United States, and Canada) and the "base," that is, the people who daily receive the gospel. (In addition, it is difficult to monitor whether and how ideas of contextualization are or may be transmitted by ministers and pastors from regional and overseas institutions after they return to their home country.)

A recent assessment of theology in Papua New Guinea indicates that, far from being over, the mission of contextualization has a long way to go. In an article entitled "Decolonizing Theology: Doing Theology in a Melanesian Context," Henry Paroi has argued that the debate on theology "has to focus more on trying to identify the inevitable link between the Christian or Gospel values and the Melanesian experience of goodness and the values of the here and now" (200I, 2I). Furthermore, theology and Christianity will have no place in people's lives unless they acknowledge Melanesian values: "The rational thinking of Melanesians and how they work and live and experience their life have to be the basis from which theology 
can flow. Melanesian theology has to have its basis in Melanesian identity and Melanesian experience of life" (Paroi 200I, 29). This line of argument implies that while Melanesians practice Christianity in their own ways and within their own particular contexts, this is not yet fully acknowledged by or integrated within western theology, and that the innovative Pacific theologians striving for a greater acceptance of Pacific values face a challenging road.

The ambivalence of organized Christianity toward the context in which it operates was also raised by Lalomilo Kamu in his doctoral thesis, "The Samoan Culture and the Christian Gospel” (published in 1996). In his introduction, Kamu wrote: "Christianity appears in some ways to be against culture or areas of life associated with the faaSamoa while in other ways it supports the culture. The Church, while existing in the same world as culture, fails to appreciate the cultural contributions to the communication of the Gospel in Samoa" (I996, 2).

Based on both Paroi's and Kamu's comments, we can safely state that even though the issue of contextualization-acknowledging indigenous cultural values and their relevance to (in this case) theology and the application of the gospel-is far from being resolved, at least a debate has been initiated, and it is one in which the voices of Pacific Islanders come through clearly. ${ }^{15}$ While there are many more Pacific Islander theologians than Pacific Islander social or human scientists, it does not mean that the example set by the theologians cannot be emulated in other areas, particularly in politics and economics.

So what can we learn from the theological literature, and how can it help us begin building a body of Pacific thought and an ensuing Pacific ethic? To try to cover all the theological material available would be a mammoth task, but we can look at selected theses and articles and extrapolate from them. Within this literature we can seek out (I) useful directions for the affirmation of contemporary indigenous concepts and the building of a Pacific philosophy, and (2) areas of accommodation or possible dialogue between foreign or universal influences and local values. ${ }^{16}$ Following this we can return to the problems of application the theologians have come across and see where the stumbling blocks lie.

\section{Lessons from Wisdom in Sāmoa}

In his 1982 bachelor of divinity thesis, entitled "Wisdom in the Samoan Context with Special Reference to the Matai System: A Theological Interpretation," Faauuga Logovae examined the various components that make 
up the Samoan conceptualization of wisdom, namely tofa, moe, and $f a^{\prime} a u$ taga. ${ }^{17} \mathrm{He}$ began by looking at the different meanings of the word tofa (for instance, good-bye, nighttime, a courteous word for sleep, a term used when addressing an orator (ie, talking chief), or the most important 'ie tōga (fine mat) received by an ali $i$ (chief), all of which are related to wisdom. Of particular interest is Logovae's explanation that, for Samoans, the mere "presence" of an orator is a sign of his or her "prudence" (ie, his tofa), implying that holding such a leadership position has certain obligations attached to it, including the duty to think things over carefully and exercise judgment and caution.

Logovae concluded that tofa is a chiefly concept because: "Tofa is more than the knowledge acquired by a person. . . . [It is] the result of many years of observation, gathering, scrutinizing, developing, improving and analysing of culture.... [The chief] observes and acquires from what is provided by nature; he also acquires from what is available in tradition and history" (1982, 5-6). The criteria thus established for leadership are of a very high standard. According to this analysis of tofa, a leader must be able to analyze, reflect, understand his or her environment, and translate all that into a "presence."

Associated with tofa is the concept of moe. Moe signifies a high degree of humility and service: it is a humble way of referring to sleep and also alludes to working on the farm or garden (because gardens are sometimes far from the village, it is more efficient to stay there in order to start farming early in the morning before the sun gets too hot). By implication, moe means that one looks after the family. As Logovae put it: "[The] emphasis is on having enough food for the family to enable them to live well. The Samoan wisdom presupposes that the person must live well" (9).

Moe is also the term used to describe the "wealth of knowledge" of the orator $(1982,9) .{ }^{18}$ But when the orator enters into relations with other matai (title-holders), "his" moe is transformed into fa'autaga. Logovae explained that fa'autaga is made up of three words: $f a^{\prime} a$, uta, and $g a$, which when combined imply the following: 19

that wisdom is a burden and an obligation for those who assume it (uta means load);

that wisdom is "shrewdness" and the ability to "consider [things] carefully," to have "sagacious and sharp insights," to be "clever or sharp in practical affairs";

that wisdom is "deeply imbedded in land" (uta means landward—it can 
refer either to the village or to where the land or forest is, depending on where the speaker is positioned); and

that wisdom is both a gift from the land and a burden so that "though [it is] a privilege, responsibilities are its constant companion." (I 3, I 5)

As Logovae noted, wisdom is a practical concept: the orator's role is not to distance himself from his people but to serve them with his fa'autaga. But it also has an ontological dimension in that it is a gift already present and "embedded" in the land.

Although Logovae's motivation for explaining the different facets of Samoan wisdom is essentially theological, his presentation contributes to our discussion in the following ways:

it demonstrates the existence of a sophisticated and integrated philosophy of wisdom and service;

it defines expectations of leadership that are relevant to and applicable in the contemporary context, and

it promotes a view of service that neglects no one and focuses on the well-being of all.

The values highlighted by Logovae are ideals (as are all values) that can and should be used in developing a Pacific-wide philosophy and ethic, and promoted in formal and informal education programs. Who uncovers or brings these concepts to light (ie, theologians or others) is less important than that the concepts be taken into consideration. ${ }^{20}$ The values should also be part of "contextualized" codes of conduct and ethics, laws, and other documents currently being considered in the Pacific. Why? Simply because they are powerfully relevant to Pacific societies (in this case particularly to Sāmoa) as homegrown concepts that people understand and that have been part of their culture and language for many years. Using concepts understood by people at all levels of society will help make leaders more accountable. While terms such as good governance, the rule of law, democracy, human rights, development, and so on are largely seen as impositions from outside and are seldom understood, long-standing local concepts embody ideals of social justice, welfare for all, service for the people, and other values in ways that make sense to and empower local people. 


\section{Examining the Vanua}

In his book Vanua: Towards a Fijian Theology of Place, Ilaitia Tuwere has argued that for the "mission of the church in Fiji . . . a proper understanding of the Fijian's concept of the vanua or land is now crucial" (2002, 7I). ${ }^{21}$ One might take this statement one step further by insisting that understanding the concept of vanua is crucial not just for the Church but for all institutions, decision makers, and citizens of Fiji, and for all those who interact with Fiji (donors, nongovernmental organizations, multilateral institutions, etc).

Tuwere's work examines key components of the vanua: the matanivanua (herald; literally, the eye or face of the land), mana (power), vakanomodi (silence), and vakarorogo or veirogorogoci (listening [to each other]). As explained by Tuwere, the role of the matanivanua is much more complex than that of a simple spokesman. He is a "mediator" who "sets in motion the principle of 'relationship' or relatedness. ... He speaks and listens, represents, reconciles, mends broken relationships, negotiates, introduces, announces and so on. Because of this rather alarming list, a matanivanua must know his vanua inside out" (2002, 72).

When reading this impressive array of responsibilities one cannot help but think: Where are the matanivanua, and why aren't they at the forefront of regulating Fijian society? Why hasn't the idea of a mediator of society - that is, someone who sees society, represents it, and acts as a communal link: "the word mata literally means eye, face, presence" (Tuwere 2002, 83)-permeated into contemporary Fiji at the national level? There are no doubt many very practical answers to this; for example, one is only a matanivanua in one's own area, so the role cannot be a national one; or, matanivanua is a traditional institution that was not designed to deal with modern Fiji. However, what we are dealing with here is not just an institution but a concept. As a concept, it can be transformed, enhanced, and reapplied to a context that has also evolved, bringing new tensions and conflicts in its wake. One of the main reasons the idea of the matanivanua has not been transposed is that it has not yet been allowed to become part of mainstream discourse in Fiji. Most people in the country, particularly within the substantial non-Fijian population, know little about the concept of matanivanua. In addition, many powerbrokers in Fiji and beyond would probably prefer that such an idea not become part of a national dialogue because it could erode the advantages they currently enjoy. And yet through the words of Opetaia Dreketirua, 
we can see how beneficial the idea of the matanivanua would be to contemporary society: "[The matanivanua] are the chords of the land (wa ni vanua) binding together the people and their leaders. They press down (bika) and hide within their own hearts the angry words of the chiefs about the people, and they hide also in their hearts the angry words of the people about the chiefs; and for this reason they are called the 'Stomach of Evil' (kete ni $\mathrm{ka} \mathrm{ca}$ ) for their first responsibility is to preserve the land from weakness of destruction through dissention" (quoted in Tuwere 2002, 83).

Another useful concept raised by Tuwere about the way of the land (vakavanua) is that of "lying straight": "the way of the vanua is davo donu (lit, to lie straight) — that is, if all live justly and peacefully with one another, with the ancestors, with God and with nature-the land would be filled with sautu (well-being)" ( 130 ). In contrast, davo cala (to lie in a crooked way) would bring disaster to the land and to the people. Both these ideas are extremely relevant to the idea of governance (and no more or less a Manichean opposition than good versus bad governance) but are richly evocative and easy to understand. They also reinforce the idea that Fijian society understands what is necessary for its well-being and does not depend on "lesson givers" from outside. These values, related to the way of the land, must now make their way into national consciousness and into the arenas of formal education, political and financial institutions, the workplace, and so on.

Tuwere's discussion of mana (a term found throughout most of the Pacific) teaches us that although it is a term closely related to the supernatural, it is also "a success or achievement oriented concept" as well as "a creative art" in that it denotes the ability to create (I39). Those endowed with mana are expected to demonstrate $i$ tovo vakaturaga"chiefly qualities" ( $\mathrm{I}_{3} 8$ ). Many contemporary chiefs lack these attributes, however. In the past, such a lack of mana would have resulted in "the rule of the club," but today "people merely grumble and speculate" $\left(\mathrm{I}_{3} 8\right)$. This inability to react is largely due to the changed conditions for succession to chieftainship: "Succession is now decided by accident of birth, determined by what is there legally in the I Vola ni Kawa Bula or official records of members of every yavusa [the largest social unit, incorporating several clans or mataqali] kept by NLC [Native Lands Commission] in Suva" (I38). Examining Fijian institutions in the context of these values may be one way to reevaluate their usefulness and relevance to the people they are serving. Teaching through both the formal and informal systems about 
ideas such as mana and $i$ tovo vakaturaga at a level beyond the superficial would provide children and adults in Fiji with firm grounding in what is expected in their society, and what they should be able to expect from others. The creativity inherent in the idea of mana could also serve as a model, encouraging confidence and initiative to develop new skills and foster new ideas.

The other components of vanua discussed by Tuwere are vakanomodi (silence) and vakarorogo or veirogorogoci (listening [to each other]), which interact with vosa (the word, speaking). Within Fijian society, "every vosa uttered is meant to be heard, to be listened to" (I73)- and not just in the ceremonial context, though that is where it is most clearly demonstrated. "It belongs to the nature of the vanua to vakatüdaliga [to make the ears stand] when a vosa is given. ... The capacity to allow oneself to hear the other is known as veirogoci and making allowances for others is veivosoti" (I73-I74). All of these components point up different aspects of the key vanua concept: one is that it "provides the governing principle in the ordering of life in the community" ( $\mathrm{I} 73$ ); another is that it evokes a large dose of humanitarianism, selflessness, and humility; and a third is that it is "intrinsic to community building" (I 75). A large part of learning is dependent on the ability to hear what the other has to say, and a large part of understanding the other is dependent on listening to them.

Tuwere is concerned with building bridges between communities in Fiji. As he sees it, "The task is to identify new modes of discernment that will permit another reading of the speaking-hearing experience of the vanua in a multi-cultural context. The experience that has proved constructive and useful in the past must re-define itself in a new situation" (I75). It is hard to disagree with Tuwere on this point. But if these values are to be upheld, they must be understood and promoted until they permeate all of society. The virtues of veirogoci and veivosoti-really hearing and making allowances for others - must be openly explained and assimilated, not maintained in obscurity and allowed to remain marginal or, even worse, considered obsolete.

\section{Future Directions}

Our brief examination of Logovae's and Tuwere's theses seeks to demonstrate that the values or elements of local philosophies they highlight, are not only relevant for contextualizing theology but also significant for understanding contemporary Samoan and Fijian society. Their work 
shows that far from being archaic, these concepts remain embedded in the Samoan and Fijian cultures, even though they have yet to enter the arena of "universal dialogue." 22 The challenge for researchers and educators (here we mean all who are involved in the process of teaching and training in any context) is to highlight and mainstream these ideas and values so that they are understood, integrated, and "recycled" into a body of thought from which a strong negotiating stance can be developed.

Not all Pacific ideals or ways of being are appealing or beneficial to contemporary society, but they must be allowed to be brought to the fore, discussed, and understood. Those that fit in with Pacific peoples' contemporary notions of well-being, health, and security should be promoted, if only for the practical purposes of avoiding civil conflict and its associated costs. It is wasteful for international and regional organizations, bilateral and multilateral funding sources, nongovernmental organizations, and national governments (and taxpayers) to spend millions of dollars trying to "clean up" devastated societies after the fact, when common sense dictates allowing those societies the time and opportunity to articulate their own approaches to the world and its multitude of developments. Many will argue that this is a luxury for which the modern world does not allow time. But if we in the Pacific do not take time, we will continue to suffer from the "maldevelopment" that is presently affecting the region, as highlighted in the many reports issued by UN agencies, the Asian Development Bank, the World Bank, and regional organizations. We need to take stock now and to listen to the voices that have remained silent for so many years. Various Pacific theologians have much to say about this, and we should enter into a prolonged dialogue with them (not as representatives of the Church but as contemporary thinkers), as should the donors and others who influence the Pacific.

The role of imaginative Pacific theologians-many can be considered the equivalent of philosophers in more secular societies-must be allowed to go beyond matters of the Church. While the media and others have sought out Tuwere's opinion about public events in Fiji, they have not consulted him in his capacity of theologian/philosopher but rather in his institutional role as president of the Methodist Church. As a high-level church representative, Tuwere may have been limited by institutional constraints. But as a free-thinking theologian, Tuwere offers a probing and enlightening discourse, which does not necessarily reflect the opinions or actions of his church hierarchy. Yet little value is currently placed on seeking out the ideas and thoughts of Pacific theologians like Tuwere, Logovae, and the 
late Kamu (many of whom could almost be considered dissidents in the sense that they critique the role of the Church) and other philosophers in the region who have spent time reflecting on their cultures' values and ways of being and doing.

Debates on public matters in the region remain very superficial. Rarely is public space made available for substantive philosophical and ethical discussion (exceptions have been a column in the Fijian language weekly Volasiga made available to Ropate Qalo to discuss Fijian rationality and related issues; the debate in Papua New Guinea on the "Melanesian Way" and Bernard Narokobi's influence in politics and law; the role played by Aiono Fana'afi in Sāmoa, etc). Policy is seldom widely debated at a public level. Local television programs are often mere propaganda tools. Instead they should offer stimulating public discussion about current issues in which local and national philosophies and views could be revealed and investigated. The ways of the land and the experiences and knowledge of rural and urban communities are subjects scarcely ever deemed worthy of in-depth media examination (beyond the shallow weekly columns such as "Countrywide" in the Fiji Times, in which young, urban-based journalists describe their one-day experience of village life-although this is perhaps better than nothing). Rather than being confined to academic discussion within theological colleges, ideas put forward by innovative theologians should be widely displayed in the media so that they can become part of the national debate and contribute to alternative ways of dealing with issues.

Let us turn now to the work of selected Pacific educators.

\section{Pacific Values and Education}

In the 2002 publication Tree of Opportunity: Re-thinking Pacific Education, which resulted from an April 200I colloquium held at the University of the South Pacific, regional educators argued for the urgent need to transform education so that it integrates Pacific values, ways of learning, and attitudes to knowledge. In her contribution, Unaisi Nabobo suggested that Pacific educators must "redefine paradigms of thoughts and explore Pacific worldviews and then take cognizance of these in formal education" $(2002,45)$. She concluded, "The coconut tree must be allowed to live with the computer tiger" $(45)$, that is, the knowledge symbolized by the coconut tree with its multitude of uses, which considerably enrich the community, must not be discarded in favor of technological, economics-driven, 
and individualized or commodified knowledge. Nabobo's views are echoed throughout the volume by the many contributors who are only too aware of the disconnected worlds in which most Pacific Islands students interact; ${ }^{23}$ of the limited opportunities for formal education available to most young people in the region (only 5 percent reach the tertiary level); and of the growing inequalities and lack of political direction in many of the countries of the region.

One of the ways Nabobo and other Pacific educators have been trying to enhance the integration of values in the curriculum has been to conduct research and promote knowledge about indigenous understandings of education, learning, and wisdom. A number of readings in an edited collection for a second-year USP course on "Theories and Ideas in Education" examine indigenous educational concepts and theories of knowledge and wisdom (Thaman ed 2003). All present similar outcomes: whether in Tonga, Fiji, Kiribati, or elsewhere, there are sophisticated theoretical indigenous constructs about learning and education. The contributions by Thaman, Nabobo, and Teaero describe what constitutes the highest and most virtuous form of knowledge in their respective countries. All of them agree that this form of intelligence, which translates loosely into wisdom, is not just accumulated knowledge. In Tonga, "poto may be defined as the positive application of 'ilo (knowledge and understanding).... Someone who is not poto is vale-one who does not apply 'ilo (with negative or detrimental results). "Ilo is therefore a precondition of poto but only through its positive application can one become poto" (Thaman 2003, 77). Similarly in Fiji, the idea of yalomatua (yalo = soul/mentality; matua = wise/mature) reflects the importance of using knowledge for the spiritual, moral, physical, and economic enhancement of oneself and others (Nabobo 2003). The concept of wanawana (the highest level of knowledge) in Kiribati also captures the importance of using what one has learnt in a judicious way for the rest of society. Quoting Taomati Nakibae, one of his informants, Teaero wrote: "A person who is wanawana is highly cultured and shows it in how he [sic] lives and behaves toward others. A person who is clever and very knowledgeable comes to nought if he doesn't practise his culture" (2003, I I3).

The readings also highlight that though these concepts of wisdom remain core values in Pacific societies, they are sidelined in the education system. As Thaman argued, "For over one hundred years, we ... have promoted (or at least accepted) [a] view of education ... that is diametrically opposed to our traditional notions of ako [learning and teaching], 'ilo 
and poto" (I995, 73I). One can say the same for all Pacific Island countries where formal curricula at best ignore and at worst denigrate fundamental principles and notions of indigenous education. That these principles have only begun to be explored in the past thirty years or so points to the weight of the colonizer in education as in other areas of public life. ${ }^{24}$

The concerns raised by Pacific educators come in the face of the consistent failure of the schooling system to produce harmonious, stable, and equitable societies despite large budgetary spending on education and extensive reforms funded by both donors and Pacific countries themselves (Taufe'ulungaki 2002). The educators are arguing for a reassessment of the purpose of education in the region and for measures to reintroduce Pacific values, beliefs, and worldviews as part of what students learn. One example of this at the tertiary level is the "Theories and Ideas in Education" course mentioned earlier, which is required for obtaining a BA in Education and for the BEd (Secondary). This course, taught by Konai Helu Thaman, focuses in large part on indigenous educational "aims, processes, content, methods and assessment" (Thaman 2000, 5 ). ${ }^{25}$ Other UsP education courses also investigate the values, beliefs, and knowledge systems of Pacific societies.

A related initiative is "the series of modules which have been developed in response to a need to assist teacher educators in the USP region [to] better contextualise their teaching" (Thaman 2000, i). ${ }^{26}$ Module 5 in the series, which looks at "Ways of Mathematising in Fijian Society," shows how sixth and seventh form Fijian students fail in mathematics in large part because Fijian concepts and values related to mathematics are ignored, and what the students are taught is culturally foreign (Bakalevu 200I). The module provides a brief overview of Fijian notions of counting and measuring, and some of the basic principles of the traditional economy, which not only give us insight into the mathematical worldview of Fijians, but also demonstrate how different these concepts are from western mathematical constructs. Understanding these differences and learning about Fijian mathematizing is not only enriching intellectually (and therefore valuable in itself) but it is essential if we are to remedy some of the problems encountered in the classroom and in Fijian society generally. One might even want to suggest that development officers and bankers in Fiji adjust their policies and methods to these concepts if they are serious about promoting the people's economic and financial wellbeing.

Another module argues that colleges of education in the region should 
take the lead in conducting research on and in studying indigenous leadership, "because leadership is likely to be one of the main issues Pacific Island countries will continue to deal with in the years ahead" (Sanga $2000,7)$. The view of the author, Kabini Sanga, is that when teaching about modern state elections, teacher educators should also discuss indigenous ways of choosing leaders. Incorporating indigenous notions of governance in the curricula "may help us to understand how to reconceptualize leadership in our schools so that [it] reflect[s] both the indigenous culture as well as modern day realities" (8). Sanga's conclusion presents a list of twenty-one areas within the topic of indigenous leadership to be researched by teacher educators and trainees. It is important that Sanga's suggestions are taken up, as leadership is already one of the main issues faced by Pacific countries. Leadership boundaries are not clear, nor are people's expectations of their leaders. Indigenous codes of conduct have been put aside while foreign ones are not applicable for many reasons. Indigenous values and principles relating to leadership have been ignored in national politics, and, increasingly, at the local level as well. Because they haven't been promoted, advanced, and publicized, they risk being left out of the debate altogether.

Furthermore, Sanga's call for teacher educators and trainers to look closely at indigenous leadership shows how important their role in reforming society can be. Teachers, like theologians and philosophers, should figure more prominently in public affairs throughout the region. We generally hear about teachers only when they are having their annual general assemblies or when they are unhappy about working conditions. Yet in the region, they constitute an important sector of an intellectually privileged minority. They should be at the forefront of promoting Pacific thought and values and should assume a public role in line with their status and with the heavy social responsibility they bear.

\section{Building the Edifice}

The work of the Pacific educators discussed here relates closely to that of Pacific theologians, philosophers, and other scholars who are concerned with contextualization and with the affirmation of Pacific thought, knowledge, values, and so on. Although they approach the issue from different academic directions, they are not only pleading the same cause but also reaching similar conclusions. The concepts they bring to the fore are applicable to all the fields they represent. This is not surprising since Pacific concepts are, by their nature, globalizing (to avoid the overused 
term holistic) and not simply theological, educational, sociological, economic, or political. Because Pacific philosophies are based on relationships and interconnectedness, fundamental concepts cover a whole range of areas of life, beliefs, and ways of doing and being. Although there are differences among communities, islands, and countries, many of the philosophical ideas are similar.

An example of this is the notion of silence, highlighted in both Tuwere's discussion of vanua in Fiji (discussed earlier at some length) and in Teaero's analysis of indigenous education in Kiribati. According to the latter: "In the Kiribati worldview, there is dignity in diligence, humility and virtue. These are demonstrated in operational terms through silence. ... Silence, in the Kiribati education context, can speak volumes and must be listened to. It takes a trained and culturally sensitive ear to "hear" and appreciate what this silence says or demonstrates" (Teaero 2003, Io8I09). The emphasis on hearing in both Fiji and Kiribati is closely linked to the idea of social interdependence, in which all members of society are considered important and none should be left aside. It is also strongly related to the ability to understand and memorize what is important to society, and to be able to transmit it faithfully. Additionally, the ability to "hear" allows for communion with the world, particularly with its supernatural component, but also with its living members. Those who "hear" are more attuned with what is going on and can better detect upcoming problems. Those who enjoy the sound of their own voices are less likely to hear those of others.

Another example of commonality across cultures is found in Nabobo's reflection on the Fijian concept of yalomatua, in which she draws parallels with Logovae's assessment of wisdom in Sāmoa (Nabobo 2003). The concept of wisdom in both these societies is similar whether one approaches it from the perspective of the educator or of the theologian. It is also a concept that can be used across the board, in governance, economics, or education, because it underpins Fijians' and Samoans' understandings of socially appropriate and desirable behavior.

These similarities all demonstrate that Pacific philosophy, as a body of thought, permeates every area of life (including the afterlife) and defies disciplinary boundaries. And despite recognizable local and regional differences in concepts and in terminology, the many commonalities point to the potential for a coherent regional philosophical construct. Building the edifice requires conducting much more interdisciplinary research and listening to the practitioners of indigenous philosophies throughout the region. 
In our next section, we examine various examples of Pacific philosophy in action.

\section{Taking Matters into Their Own Hands:}

Pacific Communities, Development, and Epistemology

Various communities throughout the Pacific have been active in promoting indigenous philosophies, but they generally have a low profile. One example of such an initiative is the TuVanuatu Kominiti, a "national movement" established out of frustration with Vanuatu's constitutional emphasis on British and French values and institutions, and its inability to promote self-sustaining socioeconomic development in spite of the country's formal independence. ${ }^{27}$ The two main activities of this movement are its bank-which deals in "pigs, mats, kava, shell money or national currency" and allows people to save as well as borrow-and its Melanesian Institute of Philosophy and Technology ( $P N B$ 1998, 7). The bank began as a community venture in 1986, expanded to the whole of Pentecost Island by 1993, and opened a national branch in Port Vila in 1996. Hilda Lini said that when in 1998 "there was a problem with the provident bank [Vanuatu National Provident Fund], people withdrew their contribution and invested it in the indigenous bank" (quoted in PNB 1998, 7). The bank issues many small loans and allows people who cannot get credit with commercial banks to borrow to set up small businesses, pay for school fees, and so on.

The Melanesian Institute of Philosophy and Technology was set up on Pentecost in 1997 but caters to students from throughout Vanuatu. According to Hilda Lini, it teaches self-reliance, instructing students to grow crops, look after domestic animals, fish, build houses, and so on, using community practices, knowledge, and skills. The schooling has six levels, the first two of which (for ages $0-6$ and 6-I2) are carried out in the home and in the village nakamal, respectively. Students age I 6 to 20 can specialize in areas such as "economy, banking, administration, to be a chief dealing with justice." Beyond stage four, the focus is on "leadership of the highest standard." Theoretical instruction is carried out in the evenings, thus respecting the indigenous timetable of evening storytelling. The students also learn indigenous writing, "a writing that was used by our ancestors" and that has been further developed by the chief responsible for initiating TuVanuatu Kominiti with Hilda Lini (PNB I998, I3-I4). ${ }^{28}$

The central aim of both the bank and the institute is to strengthen the 
community at all levels ("family, village, district, area, nation") by giving people a sense of purpose based on values they understand and respect. The by-products are increased self-esteem, initiative, social stability, security, and the ability to set goals. Such community groups may be seen as marginal (if not subversive) in the context of national politics and policymaking, and yet they provide an alternative to the critical situations some of the countries of the region are facing at the national level.

\section{"Doing Indigenous Epistemology"}

Another local community initiative, in the Solomon Islands, is documented in the article "'How We Know': Kwara'ae Rural Villagers Doing Epistemology" (Gegeo and Watson-Gegeo 200I). The Kwara'ae Genealogy Project (KGP) was initiated by a community group in West Kwara'ae in I994 to research and write Kwara'ae culture, language, and history on their own terms (Gegeo and Watson-Gegeo 200I, 66). That project, like the TuVanuatu Kominiti movement, came about in response to maldevelopment, and to the fast pace of the often negative changes occurring in that area.

Gegeo and Watson-Gegeo's discussion of the Kwara'ae Genealogy Project explains Kwara'ae "epistemological strategies," that is, the methods the Kwara'ae use to uncover knowledge. Examples are encapsulated in the concepts of abira'anga and saefilongisi(a). The first, which means to branch out, describes an approach to knowledge that follows sprouts: "As each topic or issue birabira 'sprouts into new shoots', then a closely related sprout or branch (birabira ru) can be followed via abira 'anga." Saefilongisi(a), which means "to question (it) to pieces," "connotes the knowledge that a larger idea or point is made up of small pieces or parts. . . . [and that] arriving at the conclusion, answer, or understanding of something involves everyone's knowledge and does not reside with a single person" (70-7I). These two examples (out of many more) indicate the Kwara'ae's intricate approach to knowledge. They also put to rest any notions that indigenous knowledge, or thinking about knowledge, is obsolete or static. They demonstrate the Kwara'ae's attachment to active and deliberate construction of knowledge, not only as a way of maintaining and enhancing cultural ways of doing and being, but also as a means of reinforcing a sense of responsibility and self-sufficiency in the community. Discussing the attitudes of participants in the project, the authors wrote, "project members spoke of how up to this point, cultural knowledge had been passed down orally, and it was unclear to them how it was constructed. 
Now they feel they are in the place of the elders, and they must be, as they are the generation to continue the knowledge and to continue to construct it. They have come to the acceptance of this responsibility as indigenous epistemologists" (76).

The Kwara'ae community is rebuilding what is theirs in a new light, ${ }^{29}$ one that belongs to them and uses contemporary strategies and techniques. ${ }^{30}$ The testimony of KGP participants demonstrates that although doing indigenous epistemology is "difficult work" because of both the time spent and the nature of the exercise, it is invaluable in helping rebuild individual and community confidence and in better addressing and solving community problems and disputes. One of the participants quoted by Gegeo and Watson-Gegeo is an elected kastom chief who, referring to his role in judging land cases in court, stated: "It's not only what we have done in the project, however, that has made me think more deeply. It's the confidence I've gained and the respect for traditional knowledge-that our strategies for argumentation are just as important if not more important than those of whiteman's schooling. I see other chiefs arguing in local courts along the lines of whiteman's law and ways of thinking. They cannot do it, and it only leads to confusion and passing judgments that are unfair. I see now that outsiders' ways of reasoning and whiteman's law won't fit our oral traditions of land" (78).

Gegeo and Watson-Gegeo's analysis of the Kwara'ae Genealogy Project highlights many important Kwara'ae concepts, which underpin their approach to understanding the world and to conducting research. Many of these have strong parallels with those brought up by other scholars researching indigenous methodologies and values. In addition, the Kwara'ae concepts have a strong aesthetic quality because they are closely tied to the senses, unlike many western philosophical concepts, which have become much more disconnected from both the subject and the senses. ${ }^{31}$ Examples of strong Kwara'ae imagery are concepts such as manata afe'ara'ara (mind that flows like a river or stream) to describe "a truly knowledgeable person," in opposition to olioli'a (whirlpool, that is, "repetitious and circling nowhere") to describe "a pretending but less knowledgeable person" (76).

The aesthetic quality of language and concepts throughout the region are consistent with worldviews that emphasize globalizing qualities. This is reflected, for instance, with the Kwara'ae's understanding of the "good life (mauri'a le $a$ )" in which "wholeness or completeness (ali'afu'anga)" is stressed and where development that does not focus on "the whole per- 
son (ngwae ali'afu)" is neither desirable nor appropriate (200I, 6I, 62). ${ }^{32}$ Similar notions are found throughout the region and are the building blocks to a Pacific wide ethic that must be better understood and publicized so that it becomes part of the national agenda of Oceanian societies.

\section{"Glocal" Episteme, Development, and Politics: A Fijian Example}

In the quest for appropriate development that would be beneficial to all its members, the Mucunabitu family established the Mucunabitu Iron Works Cooperative Society (MIW) using the Fijian conceptualization of the "good life" while integrating modern management principles (Qalo I997). The success of the cooperative, which began with a soli (ceremonial contribution) of $\mathrm{F} \$ 20$ from each of the sixteen subclan members and has grown consistently since its inception, defies Spate's ridiculing of the Fijian Way or vakaviti in his influential 1959 report on the economic and social problems of Fijians. ${ }^{33}$ It shows that, contrary to received truths, Fijian philosophy is not antithetical to development. It provides the example of a Fijian business using two sets of values intelligently (ie, those aspects that fit together to achieve the group's goals), in creating a "glocal episteme," or set of global-local discursive practices. The Mucunabitu Iron Works is not a perfect business; it has many management flaws, but it has avoided two downfalls common in Fiji. The first is the tendency by indigenous businesses to ignore management techniques only to struggle and eventually perish. The other is to ignore the vakaviti to the extent of becoming exploitative and "un-Fijian."

The dilemma for many ethnic Fijians, in business and politics, has been to deal with (mainly) foreigners who have consistently attempted to water down or ignore Fijian knowledge on which the former base their very existence. To Fijians, this is "upside-down thinking," which they have had to tolerate for almost a century. And although ethnic Fijians have dominated political power since their country's independence in I970, it has become clear that they have had difficulty working with the prevailing knowledge paradigms from outside. The lack of a middle ground (in the form of a glocal episteme) has led the majority of Fijians to deal with others based on their own rational world and to insist on political dominance. The instability of the parliamentary system in Fiji is in many ways akin to the collapse of the $\mathrm{F} \$ 50-60$ million Uluisaivou and Yalavou cattle schemes funded by New Zealand and Australia (and the abandoned French-funded Yaqara and American funded-Viticorp schemes): none of them hold much meaning in Fijian conceptualizations of governance and development. 
Vakaviti should be viewed as social capital (Qalo I998), as it has proven to be in the MIW case. In it are contained the following concepts, all of which enhance the common good more than the self-interest that is common among many of us who call ourselves Pacific Islanders:

veilomani (genuine concern for one another)

veikauwaitaki (caring and expressing concern for the well-being of others)

veivakaliuci (placing others ahead of oneself, supporting or looking up to them)

veidokai (honoring, respecting, and upholding someone)

Obviously much needs to be done to convince development gurus and diehard capitalists to replace the economics of fear based on supply, demand, and scarcity in our present mind-set, and allow greater space for vakaviti and similar Pacific concepts, which are based on trust and respect.

\section{CONCLUSION}

In this article we have sought to bring together some of the different facets of Pacific thought that have been explored in academia and beyond. The examples cited demonstrate that although Pacific values and worldviews remain vibrant and relevant throughout the region, they are underpublicized. The lack of a coherent voice to promote Pacific thought or philosophy means that it is discounted, particularly when it comes to policymaking. Although there are many local institutions that are (partially) derived from local customs, they have so far failed to adequately promote Pacific life principles.

Constructing a coherent body of Pacific thought does not imply standardizing or reducing Pacific concepts but rather bringing them together to find common traits. Our discussion here shows that many similarities exist. By demonstrating that there is a shared and coherent philosophy and ethic, we can "force" it onto the public agenda.

In the material we have covered, two elements stand out. First is the awareness among growing numbers of Pacific academics of the need for a genuine and far-reaching contextualization-acknowledging the relevance and applicability of indigenous cultural values in contemporary settings. Second is the success of communities whose initiatives have followed the ways they know and understand, reaping many rewards. Looking 
around the region we find many development and governance failures. The national state of affairs in many countries is not encouraging. Where good development and governance are occurring, it is usually through the direct initiative of local communities using their knowledge base. These indigenous knowledge bases must be better understood and made nationally accessible so that more can benefit. To achieve this requires a great deal more theoretical and action research into Pacific values and worldviews. Ultimately it means listening to the communities around us and giving them a chance to express their understandings of the world.

\section{Notes}

I By using the term "emergence" in the title of this article, we are not suggesting that Pacific thought is new, only that it is gradually making its way into formal academic settings. While Pacific thought has formed the basis of communal living in the Pacific for many years, it has not generally been accepted in modern discourse and institutions. Because Pacific philosophies have been transmitted orally in vernacular languages, the dominant institutions and actors in the colonial and postcolonial Pacific have ignored them. This is finally changing, thanks to all the Pacific scholars and practitioners who have been advocating Pacific thought.

2 Efforts to better understand and integrate local values into the work of missionaries began in Papua New Guinea in the I96os within the Catholic Church, in particular at the Holy Spirit Seminary. In 1968 the Melanesian Institute for Pastoral and Socio-Economic Service was established by the Association of Clerical Religious Superiors of the Catholic Church in Papua New Guinea in order to help missionaries better understand the cultures they were evangelizing. The missionaries at the forefront of this initiative "were aware that their own training had been mainly concerned with the seed and with the sower, but very little with the field" (Catalyst I99I, 7). The Melanesian Institute became a "joint ecumenical venture" among the Catholic Church, the Evangelical Lutheran Church, the Anglican Church, and the United Church from I97I. The institute's symbol, a snake wrapped around the cross, was chosen because "the snake, frequently humanised, is a group representation of everlasting life in Melanesian cultures. The cross ... is the symbol of the fullness of Christian life.... The enclosure of the two figures within the unbroken circle expresses the hope and the goal that the traditional religious concepts proper to Melanesia will one day be truly synthesised with the message of Christ" (Catalyst I99I, I I). Three Melanesian Institute publications-its journal, Catalyst, its yearly publication entitled Point, and 
its magazine Umben-all explore relationships between theology and Melanesian values and examine current issues in Papua New Guinean society.

3 Many of these theologians highlight the historical intolerance of the Church. For instance, Henry Paroi wrote, "[The] Christianity that was imparted to our ancestors ... was wounded by evils of intolerance, curse, hatred and division. This historical baggage was handed to our ancestors. . . They were taught to have nothing to do with [other denominations], they were taught not to marry their men and women thus disrupting traditional values that linked clans and families through marriage" (200I, 27).

4 Other Pacific educators working in the same area include Kabini Sanga, who coteaches a course on indigenous research at Victoria University, Wellington, and Dr Michael Mel at the University of Goroka in Papua New Guinea (Kabini Sanga, pers comm, June 2002), as well as Tupeni Baba, now at the Centre for Pacific Studies, University of Auckland. Various Māori studies and education programs in Aotearoa also offer courses with a focus on indigenous thought, research, and related topics.

5 "Native Pacific Islander" is how David Welchman Gegeo described himself in a recent article in The Contemporary Pacific (Gegeo and Watson-Gegeo 200I, $55)$.

6 Other reasons, too extensive to explore here, were raised by Edward Said in his 1993 book, Culture and Imperialism.

7 Much of the work produced by the Melanesian Institute for Pastoral and Socio-Economic Service in Papua New Guinea has either been written by anthropologists or used anthropological methods in efforts to better understand Melanesian cultures and to contextualize Christianity.

8 Other efforts exploring Pacific values and knowledge include the four-volume Science of Pacific Island People, published by the Institute of Pacific Studies (Morrison, Geraghty, and Crowl I994). This publication brings together papers presented at the first international conference on the Science of Pacific Island People, organized at the University of the South Pacific in July 1992.

9 One Samoan observer suggested that the voices have been mute because at present they are scattered and incoherent (Morgan Tuimaleali'ifano, pers comm, May 2000).

Io For instance, as Ennio Mantovani has explained, in Papua New Guinea land is part of the community; it is not treated as a commodity. Therefore, "[the selling of land] is not primarily a question of money, it is an ethical question. The same way as one cannot 'sell' one's mother, one cannot sell one's land" (Mantovani I99I, 68). Developers and donors grudgingly accept this particular ethic, which one finds across the Pacific, only because not to do so would have serious security consequences.

I I As regional academics we are frequently confronted with this discourse, adopted by many of our colleagues, administrators, policymakers, and others. 
The voices of those living their values on a daily basis do not generally permeate the walls of academia.

I2 Other voices, notably from Africa, are also questioning the domination of western thought. See, for instance, Mutua 2002; Le Monde diplomatique 2003.

I3 We are borrowing the expression "universal dialogue" from Pothin Wete, lecturer at Pacific Theological College.

I4 A South Pacific Consultation on Theological Education, held in Sāmoa in 1978 in preparation for the Fourth Pacific Conference of Churches Assembly, recommended that "local, subregional, and regional seminars on Pacific theology" be organized. The Fourth Pacific Conference of Churches, held in I98I in Tonga, concluded, "Theology in the Pacific in the past has been dominated and controlled by Western theological priorities. This has hindered the development of authentic Pacific theologies and created a 'theological dependence' on Western theology" (quoted in Kadiba 1987, I40). Dr Sione Havea, one of the strong proponents of the development of Pacific theology, was principal of Pacific Theological College in the early i980s.

I5 Some still argue that not enough Pacific Islander voices are heard-and many non-Pacific Islanders have also contributed and continue to contribute to the debate.

I6 As Ron Crocombe has pointed out, while currently the "foreign" or universal values in the Pacific are generally "western" values, the growing influence of the Asian countries in the region may result in new "outside" (ie, Asian) philosophical, religious, and political values impacting the region (pers comm, June 2002).

I7 For a detailed explanation of all the meanings of these terms, see Logovae I982.

I8 Logovae wrote, "The orator acquires, possesses and develops ... moe for the specific purpose of insuring the welfare and security of his family" (I982, IO).

I9 In Samoan, $f a^{\prime} a$ - is a prefix with several meanings; among the most common are "cause to have or do [something]," "characteristic of," or "in the manner of." The suffix - $g a$ is often a nominalizer.

20 The intent here is not to promote theologians or the role of the Church, but to demonstrate that the work of a number of Pacific theologians researching Pacific values has a potentially wide application.

2I This 2002 IPS publication is an edited version of Tuwere's PhD thesis, entitled "Making Sense of Vanua (Land) in the Fijian Context: A Theological Interpretation" (Melbourne College of Divinity, I992).

22 Entering "universal dialogue" does imply using the tools of literacy and modern scholarship to get at or beyond the Washington (and now post-Washington) consensus that determines much policymaking throughout the world. Getting ideas circulated requires publicizing them in forms that are accessible not only to the local communities engaging in them, but to a wider, influential audience. 
23 Kabini Sanga has described these worlds as "In-School" and "Out-ofSchool," explaining: "Throughout PICs [Pacific Island Countries], the world of Is and that of os are seen as distinct entities.... The Is world is one of conflicting value systems, of cultural intrusion, of identity denial, of pretensions and of compelling aspirations for things not theirs.... [The world of os] is the world of non-compartmentalisation, of being always tentative, of frequent doses of grace, of learning and working together, of competing in fun and of purposive socialisation" (Sanga 2002, 53).

24 According to Teaero, the "search for relevance in educational programmes in the Pacific started in earnest in the I970s with an emphasis on self-reliance" (1999, 74).

25 Konai Helu Thaman is Unesco Chair in Teacher Education and Culture at the University of the South Pacific. The reader used in the course draws on the work of Pacific students who follow "a conceptual model" that Thaman used to "study Tongan educational ideas while conducting fieldwork in the I980s," to write about educational concepts in their country. See Thaman 2002.

26 The series, titled "Pacific Cultures in the Teacher Education Curriculum," is published by the Institute of Education at the University of the South Pacific. As the editors explained, this initiative resulted from a research project, financed by unesco (Office of the Pacific States, based in Apia) to assess "the extent to which teacher education curricula in the region incorporated elements of Pacific cultures in the content as well as methodology of courses offered in the various teacher education institutions" (Thaman 2000, i). The need for improvements in this area led to the production of these modules. See Thaman 2000.

27 We would like to thank Motarilavoa Hilda Lini for providing us with documentation about TuVanuatu Kominiti.

28 According to Hilda Lini, "The language is made up of 38 symbols that represent sounds" and is "taken from sand drawings" (PNB I998, I4). Lini also reported that when he conducted research on this language, the chief responsible for establishing the Institute found that it was made up of two parts: the men's, who do the "talking" drawings, and the women's, who do the "counting" (or economic) drawings. Further, Lini found that other parts of Vanuatu and the rest of the Pacific have similar "symbols," which may indicate the existence of a Melanesian or Pacific writing (see PNB 1998, I4).

29 Gegeo and Watson-Gegeo noted that the Kwara'ae project began in part as a reaction against the kind of research that had taken place before in their community: "the project group wanted to create an indigenous account of indigenous cultures. For decades linguistic, anthropological, and development researchers had come to West Kwara'ae to collect data. Villagers not only felt much of this work to be exploitative, but they were unimpressed by what they regarded as very superficial questions that the researchers asked, and the non-Kwara'ae way in which they did their work" (2001, 67). 
30 One of these was to have Gegeo and Watson-Gegeo document their project in order to have their work published in English "to make it available to other Solomon and Pacific Islanders," and to have their "own voices and cultural knowledge written in their own words to be out in the public domain, just as the work of outside researchers on them and other Pacific groups is available to the public" (200I, 68).

3I Although Gegeo and Watson-Gegeo remind us that the "use of the body to know the world is an epistemological universal" (2001, 62), western emphasis on detachment and "objectivity" have done much in western conceptualization to remove the subject from her or his senses and the environment.

32 For a longer development on Kwara'ae philosophical notions of a good life, see Gegeo 1998.

33 Spate's 1959 description of vakaviti so embarrassed the Fijian establishment that they renamed it vakavanua (way of the land).

\section{References}

Aglietta, Michel, and André Orléan

I998 La monnaie souveraine. Paris: Editions Odile Jacob.

Bakalevu, Sala

200 I Ways of Mathematising in Fijian Society. Module 5, Pacific Cultures in the Teacher Education Curriculum. Suva: us P Institute of Education in association with the UNEsco Chair in Teacher Education and Culture, The University of the South Pacific.

\section{Catalyst}

I99I The Melanesian Institute. Catalyst: Social Pastoral Magazine for Melanesia 2I (I): 7-I 2.

Gegeo, David W

I998 Indigenous Knowledge and Empowerment: Rural Development Examined from Within. The Contemporary Pacific Io:289-3I 5.

Gegeo, David W, and Karen A Watson-Gegeo

200 I "How We Know": Kwara'ae Rural Villagers Doing Indigenous Epistemology. The Contemporary Pacific I 3:5-88.

IOE, Institute of Education

2002 Tree of Opportunity: Re-Thinking Pacific Education. Papers presented at a colloquium entitled Re-thinking Pacific Education, held at the University of the South Pacific, 25-27 April 200I. Suva: The University of the South Pacific.

Kadiba, John

1987 In Search of a Melanesian Theology. In The Gospel is Not Western: Black Theologies from the Southwest Pacific, edited by Garry W Trompf, I39-I47. Maryknoll, NY: Orbis Books. 
Kamu, Lalomilo

I996 The Samoan Culture and the Christian Gospel. Printed by the Methodist Printing Press, Apia.

Logovae, Faauuga

I982 Wisdom in the Samoan Context with Special Reference to the Matai System: A Theological Interpretation. Bachelor of Divinity thesis, Pacific Theological College, Suva.

Mantovani, Ennio

I99I Traditional and Present Day Melanesian Values and Ethics. Catalyst: Social Pastoral Magazine for Melanesia 2I (I): 65-8I.

Meyer, Manulani A

200I Our Own Liberation: Reflections on Hawaiian Epistemology. The Contemporary Pacific I 3: I 24-I48.

Le Monde diplomatique

2003 Le Continent noir organise son "altermondialisation": Emergence d'une voix africaine. Le Monde diplomatique Feb: 8.

Morrison, John, Paul Geraghty, and Linda Crowl, editors

I994 Science of Pacific Island People. 4 volumes. Suva: Institute of Pacific Studies, The University of the South Pacific.

Mutua, Makau

2002 Human Rights: A Political and Cultural Critique. Philadelphia: University of Pennsylvania Press

Nabobo, Unaisi

2003 Indigenous Fijian Educational Ideas. In Educational Ideas from Oceania: Selected Readings, edited by Konai Helu Thaman, 85-93. First published as Exploring Yalomatua: Fijian Education and the Missing Link, Directions I 6 (I): 4 I-54 (I994).

2002 Computer Tigers and Coconut Trees. In IOE 2002, 36-47.

Paroi, Henry

200I Decolonizing Theology: Doing Theology in a Melanesian Context. Catalyst: Social Pastoral Magazine for Melanesia 3I (I): I9-38.

Patterson, John

1992 Exploring Maori Values. Palmerston North, NZ: The Dunmore Press. PNB, Pacific News Bulletin

I998 Vanuatu's Indigenous Movement. Pacific News Bulletin Dec: 5-7, I4-I 5 .

Qalo, Ropate R

I997 Small Business: A Study of A Fijian Family-The Mucunabitu Iron Works Contractor Cooperative Society Limited. Suva: Mucunabitu Education Trust.

I998 Vaka-viti: If It Is Social Capital, Then We May Be More Advanced than 
We Think. Paper presented at the Oceania Centre for Arts and Culture Seminar Series at the University of the South Pacific, Suva, I4 October. Said, Edward

I993 Culture and Imperialism. New York: Vintage.

Sanga, Kabini

2000 Learning from Indigenous Leadership. Module 6, Pacific Cultures in the Teacher Education Curriculum. Suva: usp Institute of Education in association with the UnEsCO Chair in Teacher Education and Culture, The University of the South Pacific.

2002 Beyond Access and Participation: Challenges Facing Pacific Education. In IOE 2002, 52-58.

Spate, O H K

1959 The Fijian People: Economic Problems and Prospects: A Report. Suva: Government Press.

Taufe'ulungaki, 'Ana Maui

2002 Pacific Education at the Crossroads: Are There Alternatives? In IOE 2002, 5-2I.

Teaero, Teweiariki

1999 Re-placing Oceania Roots in our Teacher Education Programmes: A Critical Appraisal of the Roles of Indigenous Educational Ideas. Directions 2I (2): 24-45.

2003 Indigenous Education in Kiribati. In Educational Ideas from Oceania: Selected Readings, edited by Konai Helu Thaman, Io6-I I 5 .

Thaman, Konai Helu

I995 Concepts of Learning, Knowledge and Wisdom in Tonga, and Their Relevance to Modern Education. Prospects: Quarterly Review of Education (UNESCO) 25 (4): 723-733.

2000 Towards Culturally Democratic Teacher Education. Module I, Pacific Cultures in the Teacher Education Curriculum. Suva: UsP Institute of Education in association with the UNEsco Chair in Teacher Education and Culture, The University of the South Pacific.

2003 A Conceptual Framework for Analysing Pacific Educational Ideas: The Case of Tonga. In Educational Ideas from Oceania: Selected Readings, $73-78$.

Thaman, Konai H, editor

2003 Educational Ideas from Oceania: Selected Readings. Suva: usp Institute of Education in association with the UNESCO Chair of Teacher Education and Culture, The University of the South Pacific.

Tuwere, Ilaitia $S$

2002 Vanua: Towards a Fijian Theology of Place. Suva: Institute of Pacific Studies, The University of the South Pacific. 


\section{Abstract}

Among the reams of volumes published on the Pacific, mostly by foreigners (but increasingly by Pacific Islanders), only a few have examined Pacific thought and how it relates to contemporary ideas, paradigms, and ways of doing. Existing material in this area has been written mainly by Pacific theologians, educators, and more recently by native and indigenous anthropologists and sociologists. While theological works have remained essentially hidden in library stacks in unpublished theses, articles written by native and indigenous anthropologists and sociologists have been published in recent editions of The Contemporary Pacific. The voice of educators, led particularly by the usp School of Education but present also in other parts of the Pacific, is still somewhat marginal in terms of its impact on mainstream education. Put together, the work of these Pacific scholars represents an important building block for the elaboration of a body of Pacific thought, which, like an open fale, should not shut out the world but invite it in on its own terms. In turn, this body of Pacific thought should contribute to the affirmation of a Pacific philosophy and ethic: a body of applicable concepts and values to guide interaction within the region and beyond.

KEYWORDS: Pacific, thought, governance, ethics, theology, community, education 